\title{
ART AS A REDEFINITION OF HISTORY IN PRAXIS PHILOSOPHY
}

Slađana Kavarić, University of Montenegro, zarathustra.kavaric@gmail.com

10.31902/fll.26.2019.17

UDK 7.037:1

\begin{abstract}
The paper aims to show that aesthetics as a demand for the meaning of society is fundamentally historically based and indirectly directed towards the redefinition of historical experience. This issue is important because a globalized, technologized society has a demand for non-standard, artistic thinking. This view is worth looking into as a historical precondition for the technologization of everyday life, and to emphasize that art, as an interpreter of this, is an important segment of the justification of the need for self-understanding in the historical context. Ideology as a dimension of historical reality often has an impact on the artistic, which again, in a certain sense, acts as a re-filter of what is already defined in time. In this way, the question arises as to whether artistic insights are limited and overcome, or art is the challenge of today's as well as historical experience. Through analysis Praxis relation to art, a space for understanding the relationship between art and history opens up and questions about the boundaries and the consequence of such a relationship.
\end{abstract}

Keywords: history, praxis philosophy, aesthetics, technology.

\section{Introduction}

The understanding of the continuity of philosophy, as well as of the overall significance of historical and spiritual material is impossible unless there is a certain form of systematization of historical heritage. The intention to notice, define and understand the structure or contradictory course of certain thought content, is subject to a basic requirement to find, often in eclectic structure of philosophical thoughts, a connection and/or a common substantiality. Jaspers remarks that history is the happening of transient events in which the being of eternity is being manifested (Jaspers 2008, 11). In this sense, history provides not only vitality to philosophy, enabling sometimes its survival even through completely non-philosophical periods of time, but also it significantly contributes to comprehension of the overall human spiritual, intellectual experience. The understanding of historical aspect is more important to philosophy than any other discipline. Perhaps one of the most significant reasons for that is reflected in the complexity, the unevenness, but also in the discontinuity and degradation of its development. Also, although the characteristic of philosophical 
thought is very complex, it often faces a restricted conviction, typical for specific sciences, that true philosophy is only the one of the latest date (Korać 1978, 8). Such tendencies of misinterpretation of developmental complexity of philosophical thought do not contribute to the understanding of philosophy, but exclusively to the reduction of its significance, since the entire philosophy is being unequivocally simplified and mutilated. Since Hegel determined it as the middle between direct sensuousness and ideal (Grlić 1965, 9), art should unquestionably be taken into account when considering the historical development process. Following the attitude of Gajo Petrović, that history is an indispensable form of one's life and the only possible area of his social movement (Petrović $1978,140)$, it is important to process the role of art in that time frame and its influence on the mentioned movement. Praxis philosophers determine a man as a being of practice, and practice as a creative activity and development of the greatest human possibilities, opposed to needs and normative (Golubović 2007, 17). Historical datasets are subject to redefinition and establishment of new layouts for interpretation and activity, primarily in order to shape the present. Art is one of the most significant forms of influence on seemingly factual, and the present is a common consequence of what it used to be, as well as a creative reaction on time continuum.

\section{The Problem of Historicity of Philosophy}

Historical consciousness about thinking engagement such as philosophy, provides a continuous understanding of the essence of philosophical heritage. An effort to have the philosophical heritage contemplatively included is endeavor in order to understand the philosophy itself. Without history, today's philosophy does not make sense, and the future has no rational foundation. It is a space in which time relativizes, since the past and the present do not mean much individually, but at the same time they sum up the value and create a system that is much more significant than their capacities individually. Jaspers points out the unbreakable connection of the past and the present, noting that history is real exclusively as the existing present. "The present does not result from itself, but from the past. Historically self-aware, one indicates to the past. And again, the past should always be understood as his present" (Jaspers 25).

Nevertheless, not only did the attitude towards the past change through different philosophical periods, but it often differed among the philosophers of the same period, considering the need for instrumentalization of previous opinions on behalf of specific philosophical systems. For Greek philosophers, as Veljko Korać remarks, the attitude towards the past is defined in two terms: some of them adopted the thoughts of predecessors, ${ }^{1}$ while others criticized the

1 Korać states that, primarily, the examples of Eleaticism, Stoicism and other similar shools speak 
predecessors or opposed their worldview (Korać 10). Plato's example quite convincingly demonstrates how the relationship to the previous standpoints matters, not only for getting acquainted with the thoughts that were present, but also for understanding and analyzing the interaction between the given concept and the one that followed it. In that sense, Plato has pretty much contributed to actualization of Socrates's philosophy, although Plato's interest in thoughts that preceded him was definitely "motivated by the needs of his philosophy system" (Korać 11). His disciple Aristotle, gave even greater contribution to the comprehension of the overall Greek philosophy, because in Metaphysics he made a unique acknowledgment of philosophical inheritance, considering it an indispensable, fundamental part of his system. For this reason, Aristotle is considered to be the founder of the history of philosophy and he represents the reference point for its methodical and systematic study (Korać 15). However, until Hegel, the status of the history of philosophy was not clearly defined or at least it was notgetting the attention it unquestionably deserved. The complexity and specific complexity of comprehension of this concept, mostly justified by the multitude and the variety of philosophers and their thinking tendencies, have degraded the status of the history of philosophy. "Many authors consider the history of philosophy, if not totally incompatible with philosophy, then to be poorly connected to it, so it could be neglected in that sense" (Grasija 2002, 311).

Although he belonged to the modern philosophy tradition, Francis Bacon ambivalently, but still at the expense of the history of philosophy, claims that

endless repetitions of the same thing, varying in the method of treatment, but not new in substance, insomuch that the whole stock, numerous as it appears at first view, proves on examination to be but scanty. (Bacon 1964, 12)

The history of philosophy does not necessarily mean continuous progress, but respects the preceding thought material in terms of participating in each of the following, at least in a form of reactive deviation from, until then, dominant philosophical strivings. Thus St. Augustin relies his work The City of God on the testimonies of Diogenis Laerti, and he selectively presents Greek philosophers whose opinions are at least speculatively based on Christianity. A reaction to philosophical material can also be seen vice versa, in the example of Descartes, who desperately opposes the theologization of Aristotle's thoughts, protecting the omnipotence of metaphysics (Korać 25, 27). This kind of endeavor for thought to find its initial base in philosophy of other philosopher or other philosophical tradition, is a contribution to the history of philosophy, since that way it shows the expansion of thought's boundaries, and their undeniable up-

in favor of the appreciation of privious philosophical achievements. 
grading and interdependence. However, certain authors, first of all prominent representatives of the analytical school of thought, such as the founder of logical positivism and Vienna school Moritz Schlick and Ludwig Wittgenstein, considered the studying of the history of philosophy as meaningless endeavor. How unreasonable it is to study the chaoticness of the history of philosophy, Schlick clearly expresses with the statement that it's "the area of infinite cognitions of thoughts and contradictions, rather than being a harmony of thoughts and some kind of universal agreement" (Korać 30). Wittgenstein has a similar tendency to underestimate the significance of philosophy, which he reduces to a logical systematization of thoughts, that clearly stands diametrically to numerosity and insolvability of historical philosophical problems. By partial insight into the historical status of the history of philosophy, conclusion can be made that the actuality of historical approach to philosophy was equally complex, sometimes even relative, as was the legitimacy of its content. The self-identification of thought with its creation time with what it was in an unfinished form of someone else's system, is one of the basic characteristics of historicity of philosophy. Jaspers writes that "by understanding itself, by expressing and explaining its essense to itself, philosophy, simultaneously, discovers what it was until then" (Jaspers 40) and, thus, he suggests that self-awareness is the foundation of the history of philosophy. It seems that what is substantial in philosophy is the observation of what is essentially common to all thought systems, and reasoning about nature of their formation and cause-effect relations. "Historical presence carries philosophy, allowing the content to permeate into it until reaching the self-awareness; philosophy is the clarity of the epoch beyond which, according to Hegel, it can never step out" (Jaspers 31). By comprehending the philosophical thought as it was, giving it a rational historical foundation and timeless meaning, Hegel becomes one of the founders of the history of philosophy as a science. The necessity of existence of philosophical heritage is being justified by the necessity of developing the future thought material in order to achieve the absolute mind, which completes not only Hegel's philosophical system, but also enables creating the historical circle of philosophy. On the other hand, Praxis philosophy should express the fundament of such historicity.

The interpretation of practice assumes a certain philosophy to be a whole. And the truth is exactly the whole of development. This means that the beginning can only be talked about in the end, that is, that the end shows in essence what used to be at the very beginning. The beginning without the end is not even beginning, for whose would be the beginning, when nothing comes out of it. )Bošnjak 1964, 7)

The consequent, the creative, which lies in the basis of practice, is one of the frameworks for defining and relation to the past. 


\section{Praxis as a Creative Redefinition of Former Principles}

The practice issue is one of the fundamental problems in defining human existence. It is conceived in conjunction with alienation and, therefore, it doesn't cover only what man is, but also the overall potency of the human. This philosophical position reduced Marx's point of view in a direction of creative, live and authentic Marxism, that stands directly and unequivocally against dogmatism. The attempt to actively think through the problems of a certain time, requires the reliance on the past times, in order to enable the broader context analysis, the historical connecting, and to perceive the cause and effect relationship. Vranicki claims that each stage of human thought is determined by certain historical and thought traditions. "Illuminating his existence and its sense with thoughts, devising his own beingness, the overall man's thought effort proves to be a sort of very complex, often very transparent history of his mind" (Vranicki $1964,35)$. Therefore, the thought must be active and time-based.

It must be at the level of the best realistic opportunities of history and historical occasions particularly appropriate to it, in order for these opportunities to be awakened, and as a thought to prepare a new history and to creatively contribute to its realization. (Golubović 19)

Practice has always been defined in relation to theory. Grlić sees it as all the concrete activities in the sphere of sensory-material reality, which are substantially different from those in the sphere of intelligible thought (Grlic $1968,5)$. If something is more reconciled with social givennesses surely meditatively and passively, then it is more opposed to practice, which implies quite contrary spiritual and practical tendencies. Human practice, in the true sense of the word, is not reconciliation with facts, with objective, social imperatives and determined norms, but its main characteristic is the request for changing, it is an active engagement in a reality structure (Grlić 8 ). The fundamental function of practice is a lack of agreement with what has been given and redefinition of all existing facts, in order to determine the true meaning of those facts, to expand the range, and to examine the importance more closely. It does not imply the actualization of the past for itself alone, but in order to examine the more progressive and more complete possibilities of the new, practice reanalyzes the past. By carrying in itself the elements of projection in something that does not exist yet, but is only possible (Grlić 9), practice extends with the real originative and creative element which has always been on the tendency to conceptualize (further) the future and in that way to make an impact on what is about to happen. The dogmatism, or merely reception and the uncritical acceptance of the given, is not possible as a practice, so it exclusively exists as a contradictory term 
that should not be considered practice, for it would be a profound antinomy. The normativity of certain thought movements, which are somewise characteristic for certain currents within Marxism itself, make the interpretation of that paradigm more complex, considering the fact that it is not a one-dimensional and unique way of thinking, but it is both complex and often uncatchable. Nevertheless, the Praxis orientation philosophers are clearly determined according to practice - it must imply overcoming the given and overcoming the objectively possible. That does not mean that one should go into surreal space of the impossible, but it implies a constant effort to understand further and to establish new boundaries of the potential, all this in accordance with what the past set as a limit of its capabilities. In that sense, practice is a form of idealism, which is specific and does not cross the boundaries of reality.

Criteria of practice are positive ideals. Practice is directed towards a positive goal and it means the way and the content of movement towards its realization. Practice is guided by ideas, and ideas get their concrete content in practice. (Bošnjak 19)

This particularly refers to artistic work. Danko Grlic realizes that the undogmatic, that is, the thinker of praxis, motive for thinking about the artistic and cultural state in society find precisely in "the dissatisfaction with its pale, deadened, stable, always the same 'practical' effects on the general public plan" (Grlić 18). Being engaged in this form of practice means revision in order to seek a better quality support in the past. That sort of factual disruption enables the progression in its comprehension and breaking the schematized principles, that, such revised, serve to a better definition of the present. "We can also say that praxis is historical beingness or beingness through the future" (Petrović $1964,22)$. In that part, the present and the past are mutually dependent, for it's historically necessary material for creating the future. The opinion, therefore, implies one of the available processes of continuous disclosure and debunking, in order to remobilize the valid structurality and to make a step further in the existance, which inevitably means setting the foundation for freedom, and, in relation to that, providing the necessary humanization of society as well.

\section{Opinion on Freedom - Awakening of Humanity}

Praxis is, according to Gajo Petrović - one of the most important Praxis philosophers - a universal, free, creative and self-creative beingness. In the essence of defining a man by praxis being, there is a request for freedom, for individual transparency, which should contribute to the overall humanization of the community. Nevertheless, Grlić warns that freedom should not be mis- 
understood and reduced to the freedom of speech, opinion or actions, but it should be seen as the structural foundation of the whole human being (Grlić $1968,39)$. Although the problem of freedom is often treated from the society aspect, such rejection of the individual and freedom depending on superpersonal, significantly destroy freedom and dehumanizes a man. Humanization requires a permanent struggle to overcome the given freedom degree and not settling down before the supposedly fully reached freedom, which is imposed from the outside. True freedom is, according to Grlić, a process and its foundation and source are not in the achievement of freedom, but in its constant creation (Grlić 1968, 43). In order for philosophy as a discipline to encompass and understand the concept of freedom, it has to, first of all, take the humanity into consideration, which, as a broader term that creates a perfect ground for expression and development of freedom, allows philosophy to "truly begin to think freely about freedom" (Grlić 1968, 45). This implies that the realization of true freedom is inextricably linked with the demand for creating an adequate atmosphere for its realization. Thus, the thought, no matter how free it is, without the premise of the climate that is ready for it, has no significance, and the area of immanent freedom is created precisely by the efforts of the thought to affirm and establish it. In this manner, Marcuse also believes that humanism today means parting with the existing one (Marcuse 340). Like freedom, it cannot be a mere term that needs to be defined, but the process that needs to be realized. In this sense, we can not speak of humanism and freedom as fixed categories that have already reached the level that should be accepted (Grlić $1968,47)$, on the contrary, it is about the critical attitude, reconsideration and finding out the further possibilities for their realization. But is not such demand possible in a contemporary society, in which the artistic and the creative are subordinated to the technologized reality? Can one talk about art and creation, which primarily contribute to humanism, when human society is conditioned by dehumanized technologization that overcomes it? The society crisis, according to Max Horkheimer, is causing the science crisis, as well as the philosophy crisis, hence the impotence of the overall creative awakening. By expressing the fear that the instrumentalization of science reduces it on the indirect causes of the overall society crisis, as the mind is perceived as functional rationality, this author warns that "the moment of disorganization enters the science to the extent in which the interest in overcoming the existing substitutes the interest in better and more humane society" (Kučinar 1976, 12). The artificial creation of false possibilities leads to the paradox of freedom, for it seems that there is too much of freedom, however, there is less and less of humanism. This antihumanism is often politically motivated and it suits the centers of power which, with an apparent availability of everything and under a cloak of allegedly never greater freedom, enslave the same. 
The society of abundance is a system of false needs, namely, needs for goods, achievements, professions that make one more dependent upon the apparatus of government, and the apparatus is being constantly strengthened and expanded. (Marcuse, 334)

The creativity is then in a supporting function of the already permitted freedom limit, that is not being asked about the overcoming, because it is about the tightness that the art's subject, but also any thought subject, cannot effectively make an influence on. In that closed society, a certain type of man is being developed, that cannot and will noy say no any longer, whose "no," even if he says it, again has an affirmative character: the inability of contradiction, the inability of transcendence, and not only in practice, but in thinking and feeling. The contraposition of humanism, which stands on the side of tendencies that stultify it, shows not only its limit, but also its dependence on the social, and, in a wider sense, on the historical. Although in such ambient of clearly defined actions and same-mindedness, with the abundant production and technical ability of the system, it seems pointless not to consume the offered and to declare a war in hope for the realistic possibilities of humanism (Marcuse 334), Grlić refuses to fully accept the pessimistic faltering before the current, and he calls for finding out the meaning of art, just when any question about the meaning of art is being rejected, in the society that develops indifference towards the authentic and everything that is not directly usable (Grlić 1968, 89). Though humanism is a goal that freedom, as still insufficiently developed category, has in front of itself, it seems that it's far from its zenith and it's often regressed by the dominant instrumentalization and the eclipse of the creativity. Nevertheless, only individual action directed towards the authentic creation, resisting the existing, can contribute to the collapse of the same-mindedness, because our world, now more than ever, needs "individuality, unconventionality, extraordinary enthusiasm, spontaneity, genuine eruptive power and humane revolt of art" (Grlić 1966, 137).

\section{Art and Technologization of Everyday Life}

Art is always a tendency to reassess the validity of the current and the effort to move the boundaries of it forward. Such a request almost necessarily involves reconsidering the previous one, because a progress is not possible if it is not examined in what direction and in what way it is possible, and that is achieved exclusively through the recognition of the historical. In this way, the future is being redefined history and a new conclusion derived from the historical experience. Grlić particularly emphasized the significance of art and its inseparability from the thought, and from philosophy. And what is art if not 
a possibility of creativity in a historical context and overcoming its borders by reviving the historical aspect of the artistic. Also, the forementioned author seems to believe that the basic question about history is not consideration of the origins of the previous forms, but the question of a potential of the truly human (Grlić 1968, 93). By taking into consideration the history of art, before us is a subject that is above time and shows the continuity of the artistic character of human nature. Although one should not ignore the fact that "the whole process of creating art is ambiguous by its nature: the artist finds out reality and makes his own reality at the same time" (Eko 1977, 228), such kind of treatment and shaping of reality often shows the closeness between history and art, and often shows the impossibility to demarcate these areas, which as a consequence often has an undisturbed relation of the certain works of art to the specificity of a historical period. If art is defined as something contrary to invariance and conservation, as a process of change and development, then we assume that it depends on conditions of external givenness. Adorno sees work as "a constant dissolution, therefore, not just the one-time act, but a change of state as a process, a continuous dialectical movement" (Grlić 1986, 100). Such actualization in time, necessarily involves reality as a participant in the process of establishing the artistic, but also the artistic as an interpreter of the events that it overcomes. In principle, such a viewpoint is also confirmed by communicologist Toma Đorđević, who considers the art work, regardless of the space of materialized effects of the creative act, according to the classically normed criteria of aesthetic treatment of the work, as a medium that overcomes the realistically given reality (Đorđević, 2006, 263). Hence, the possibility of authentic artistic activity is not directly dependent on the external, primarily economic and technical tendencies, since its subject is already beyond that kind of realistic. However, it does not presuppose that the artist in the creation process does not participate in historical, at least in terms of rejection of its heritage, which in a certain way causes the technicalization of reality.

Ivan Focht believes that true art, even the contemporary one, is neither quantitatively nor qualitatively less present than before, since there have always been very few artists, two or three in each art form (Focht 168). Although the idea of an independent individual stands in contradictory relation to social development and technical possibilities, because the hyperproduction leaves less room for freedom and isolation beyond the imposed needs, the creation process may only present itself as a form of authentic creativity in such realistic environment, an its value is precisely in that resistance and opposition to reality, which is in many ways disadvantageous for survival of immaterial values. Not excepting the fact that the reception of art nowadays is often adapted to the pragmatism of usable value, yet there is no reduction of the dimensionality of its historicity, especially if we consider the role that art has in redefining the historical and in assuming the future. 
For art can not truly vanish in our time, as no man has disappeared either, trampled upon, humiliated, crushed, blended and embedded into the amorphous, supraindividual mixture, a man massacred so much in his humanity, but a man from whose crucifixion and torments, astoundingly, always the new seeds of humanity emerge anew. (Grlić 1966, 165)

Even though it changes itself historically and it's not immune to the global tendencies of the overall consumer (dis)course, art processes reality and re-establishes it even when it is subject to the dominant historical stream. The omnipresence of the generally accepted truths, that the whole society is subjected to, consequently strives to robotize an individual and put him into a framework, within which he will be manipulated into playing the role for the system account, and at the expense of enlightenment of self-identity. Although not rejecting praxis, quite the opposite, by believing in coping with such encapsulated social state by means of human progress and cultural self-recovery, it doesn't seem unconvincing to abandon the faith in revolutionary freedom achievement, in the collective, since revolution no longer represents the reference point of social conditionality and the symbol of a certain relation to the historical. Art, in this sense, can be undoubtedly effective, considering that its foundation is the reaction that is based on the examination of what causes it. Despite the fact that it often refuses to declaratively refer to history and to put itself into the service of time, the artistic engagement reconsiders time, redefines it anew and it seems to be an indispensable characteristic of the creative endeavor. Because, according to the Praxis philosophers, "there are only two fundamental alternatives in contemporary world: to simply give oneself over to the established historical course or to take history into one 's own hands and to act" (Grlić 1968, 139), or better still - to act artistically.

\section{Conclusion}

Among the praxis philosophers, of whom we particularly emphasize Danko Grlić, who's been mostly dealing with the relation between art and contextual framework, a clear request for creative revision has been made, in order to enable development and progress. Following this author's thought that tradition is being negated only when it's being criticized, it seems that art criticism is one of the most impressive forms of revival, and then overcoming the past. Such denial of the past in order to its affirmation in a different and more valuable form is a necessary condition for development. Art is most often interrelated with history, so Lukac's claim that the art has been created by human will, which is directly influenced by reality reception, seems to be relevant (Lukač $1979,31)$. This kind of creation, stimulated by consuming the outdated, is a 
way to understand the old in order to create the new, to redefine and prepare the terrain for some future stage of historical development and position of observing the past, whose subject will be this present as well. The dialectism of such perception of the role that art has in defining the historical, requires each interpretation to be determined as creation, since it's not just about defining, but rather about redefining, hence, about something that is subject to unlimited, that is, to different re-treatment. Although through the technologization of society and reality, the authenticity of art is often being called into question, it seems that it is the only response and resistance to the tyranny of techniques and materialization. Freedom, which is the fundament of creativity, must be and is humanistic if it wants to achieve true self-awareness, and without that aspect, art is not able to freely think of freedom. History, on the other hand, allows art to evolve and, in its historical progress, to re-establish its foundation, by creating the whole new identity that is subject to questioning by some new artistic redefinition.

\section{Works Cited:}

Bacon, Francis, Novi Organon, Naprijed, Zagreb, 1964.

Bošnjak, Branko, „Ime i pojam praxis“ u: Praxis, No. 1, Zagreb, 1964.

Đorđević, Toma, Estetika; komunikološki aspekt, Institut za političke studije, Beograd, 2006.

Eko, Umberto, Estetika i teorija informacije, Prosveta, Beograd, 1977.

Focht, Ivan, „Umjetnička tehnika i tehnifikacija umjetnosti”, u: Praxis, No. 2, Zagreb, 1966.

Golubović, Veselin, Filozofija kao mišljenje novog, Euroknjiga, Zagreb, 2006.

Grasija, Horhe, Filozofija i njena istorija, Filip Višnjić, Beograd, 2002.

Grlić, Danko, „Čemu umjetnost”, u: Praxis, No. 2, Zagreb, 1966.

Grlić, Danko, Izazov negativnog, Nolit, Beograd, 1986.

Grlić, Danko, Umjetnost i filozofija, Mladost, Zagreb, 1965.

Grlić, Danko, Zašto, Studentski centar Sveučilišta u Zagrebu, Zagreb, 1968.

Jaspers, Karl, Svetska istorija filozofije, Fedon, Beograd, 2008.

Korać, Veljko, Filozofija i njena istorija, Naprijed, Zagreb, 1978.

Kučinar, Zdravko, „Predgovor”, u: Maks Horkhajmer, Tradicionalna i kritička teorija, BIGZ, Beograd, 1976.

Lukač, Đerđ, Estetičke ideje, BIGZ, Beograd, 1979.

Marcuse, Herbert, „Humanizam - ima li ga još” u: Praxis, No. 3, Zagreb, 1970.

Petrović, Gajo, Mišljenje revolucije, Naprijed, Zagreb, 1978.

Petrović, Gajo, „Praksa i bivstvovanje” u: Praxis, No. 1, Zagreb, 1964.

Vranicki, Predrag, „Uz problem prakse“ u: Praxis, No. 1, Zagreb, 1964. 